\title{
Online shopping behaviour of the consumers in Jorhat town of Assam
}

Manorama Devi, Leena Das and Moonty Baruah

Received: 03.05.2018; Revised: 19.10.2018; Accepted: 01.11.2018
See end of the paper for authors' affiliations Manorama Devi

Department of Family Resource Management and Consumer Science, Assam Agricultural University, Jorhat (Assam) India Email : manoramaaau@ gmail.com
ABSTRACT : Online shopping is purchasing items from internet retailers. Recently it has witnessed a tremendous growth resulting in greater use of this tool by the traders. Also the competition in e-commerce is intensified. Therefore, it becomes more important for online retailers to understand the online shopping behaviour of the consumers. Consumer behaviour has been always of great interest to marketers. The knowledge of consumer behaviour helps the marketer to understand how consumers think, feel and select from alternatives like products, brands and the like and how the consumers are influenced by their environment, the reference groups, family, and salespersons and so on. For the present research work 120 samples were selected randomly from four wards of municipality area of Jorhat Assam and a multistage stratified random sampling method was adopted in order to select representative sample. Findings revealed that majority of the consumers have average shopping behaviour. Age of the respondent is negatively correlated whereas education and income has strong positive correlation with online shopping behaviour.

KEY WORDS: Consumer, Consumer behaviour, Online shopping, Online shopping behaviour

- HOW TO CITE THIS PAPER : Devi, Manorama, Das, Leena and Baruah, Moonty (2018). Online shopping behaviour of the consumers in Jorhat town of Assam. Asian J. Home Sci., 13 (2) : 538-544, DOI: 10.15740/HAS/AJHS/13.2/538-544. Copyright@ 2018: Hind Agri-Horticultural Society. 